\title{
Feasibility assessment of a tunnel-ventilated, water-padded barn on alleviation of heat stress for lactating Holstein cows in a humid area ${ }^{1}$
}

\author{
T. F. Shiao, ${ }^{*}$ J. C. Chen, ${ }^{\star}$ D. W. Yang, ${ }^{\star}$ S. N. Lee,$\dagger^{2}$ C. F. Lee, $\ddagger$ and W. T. K. Cheng§\# ${ }^{3}$ \\ ${ }^{*}$ Animal Industry Division, \\ †Animal Physiology Division, and \\ ¥Nutrition Division, Livestock Research Institute, Tainan 71246, Taiwan, Republic of China \\ §Department of Animal Science and Technology, National Taiwan University, Taipei 10672, Taiwan, Republic of China \\ \#Department of Animal Science and Biotechnology, Tunghai University, Taichung 40704, Taiwan, Republic of China
}

\section{ABSTRACT}

The use of evaporative cooling for mitigating heat stress in lactating cows in humid areas is controversial. In Taiwan, Holstein cow performance is significantly restricted by hot and humid weather. This study investigated the efficacy of using a tunnel-ventilated, water-padded freestall (TP) barn for reducing heat stress in lactating cows. From August to October 2006, 36 cows allocated in a $3 \times 3$ Latin square were raised in 3 barn cooling treatments: a conventional freestall barn with fans and sprinklers in the feed line (Fan+SP, control), a TP barn, and a TP barn with sprinkler cooling $(\mathrm{TP}+\mathrm{SP})$. Daytime air speeds in the 3 barns were $1.23,2.38$, and $2.06 \mathrm{~m} / \mathrm{s}$, respectively. Both TP barns were more efficient than the control in reducing the daytime temperature and temperature-humidity index. The barn temperature was $<26^{\circ} \mathrm{C}$ for an extra $4.2 \mathrm{~h}$ per day, but the relative humidity was $>96 \%$ in both TP barns. Cows in both TP barns had higher respiration rates and skin temperatures at $0300 \mathrm{~h}$ than cows in the Fan+SP barn. The TP environment increased the cows' serum cholesterol level and the activities of alkaline phosphatase and alanine aminotransferase, but blood partial pressure of $\mathrm{CO}_{2}$ was not affected. Vaginal temperature was persistently high in cows in the $\mathrm{TP}$ barn; in the $2 \mathrm{SP}$ barns, it decreased 0.4 to $0.6^{\circ} \mathrm{C}$ following sprinkling and milking. The intake activity and rumen digestion of cows raised in the 3 environments were similar. Cows in both TP barns ingested more dry matter. Cows in the $\mathrm{TP}+\mathrm{SP}$ barn tended to produce more milk than those in the Fan+SP barn (25.4 vs. $24.7 \mathrm{~kg})$. Although heat stress was not completely alleviated in these 3 barns, the $\mathrm{TP}+\mathrm{SP}$ treatment resolved the negative effect of a previous TP barn built in 2004

Received August 17, 2010.

Accepted June 10, 2011.

${ }^{1}$ Contribution No. 1577 from the Livestock Research Institute, Council of Agriculture, Executive Yuan, Taiwan, Republic of China.

${ }^{2}$ Retired

${ }^{3}$ Corresponding author: wtkcheng@ntu.edu.tw on intake and milk yield by increasing air speed and using sprinkler cooling. Thus, it is expected that $\mathrm{TP}+\mathrm{SP}$ barns will be beneficial in regions with high humidity. Adequate air speed and sprinkler cooling are likely to be key factors for further study.

Key words: heat stress, lactating Holstein cow, humidity, tunnel-ventilated and water-padded barn

\section{INTRODUCTION}

Because of their large body size and high metabolic rates, lactating cows, especially high-producing cows, are extremely sensitive to heat stress. Environmental contributors to heat stress include air temperature $(\mathbf{T})$, relative humidity $(\mathbf{R H})$, solar radiation, air speed, and their interactions. When the effective $\mathrm{T}$ is higher than the animal's thermo-neutral zone or comfort zone, heat stress occurs (Bianca, 1962). To dissipate the extra heat, cows look for shade and increase their drinking, sweating, urination, and panting rates (Bucklin et al., 1991; Smith et al., 2006a). If heat dissipation is inadequate, serious heat stress will result in higher body $\mathrm{T}$ and lower DMI, milk yield, and reproduction performance (West, 2003).

Taiwan is an isolated island located in subtropical Asia. For the last decade, the average monthly $\mathrm{T}$ and $\mathrm{RH}$ during the hot summer months have reached $27.1^{\circ} \mathrm{C}$ and $84 \%$, respectively (Table 1 ). In addition, persistently high humidity even worsens the environment for cows in Taiwan. Heat stress, which is significantly detrimental to cow performance, is the main challenge to our dairy industry. Beede and Collier (1986) suggested that improving the barn environment is the most effective and direct method to alleviate cow heat stress. Barns that provide shade to cows are necessary in Taiwan. Feed line fans and sprinklers cooling, which were introduced from Israel, decrease cow rectal $\mathrm{T}$ and respiration rate $(\mathbf{R R})$ and effectively stimulate feed intake (Lee et al., 1999). However, the barn temperature-humidity index (THI) of the cool, warm, and hot seasons remains high even in well-managed dairy farms 
Table 1. Monthly average air temperature and relative humidity (mean $\pm \mathrm{SD}$ ) at the Livestock Research Institute of Taiwan from 2000 to 2009 (Meteorological Station B2N89) ${ }^{1}$

\begin{tabular}{lccccccc}
\hline & \multicolumn{3}{c}{ Temperature, ${ }^{\circ} \mathrm{C}$} & & \multicolumn{3}{c}{ Relative humidity, $\%$} \\
\cline { 2 - 3 } \cline { 7 - 9 } Item & Mean & Maximum & Minimum & & Mean & Maximum & Minimum \\
\hline No. & 60 & 60 & 60 & & 60 & 60 & 60 \\
Cool season $^{2}$ & $20.2 \pm 2.6$ & $31.4 \pm 2.2$ & $10.6 \pm 3.5$ & & $80.5 \pm 3.6$ & $99.4 \pm 1.2$ & $36.0 \pm 8.1$ \\
Hot season $^{2}$ & $27.1 \pm 1.1$ & $35.1 \pm 1.2$ & $21.1 \pm 2.3$ & & $84.0 \pm 3.5$ & $99.9 \pm 0.3$ & $46.2 \pm 8.9$ \\
\hline
\end{tabular}

${ }^{1}$ Mean data were calculated across days in a month. Maximum and minimum data were obtained by averaging the extreme data from each month.

${ }^{2}$ Cool season $=$ November to April; hot season $=$ May to October.

(66.3, 75.7, and 79.8 , respectively). Thus, the cows still suffer heat stress (THI >72) for two-thirds of the year (Chen et al., 2009).

Tunnel ventilation used in a pad-cooled barn contributes to heat stress relief. Evaporating water in the pad absorbs heat from the incoming air. The resulting cooled air removes body heat when it flows over cow body surfaces. In dry areas, using water to evaporate heat has been shown to effectively reduce cow heat stress (Bengtsson and Whitaker, 1988; Ryan et al., 1992). However, the presence of high humidity causes concern regarding the use of water to relieve heat stress in humid areas. In the hot, humid climate of Mississippi, Smith et al. (2006a,b) showed that combining tunnel ventilation with evaporative cooling decreased cow exposure to mid-heat stress, increased feed intake and milk yield, and decreased milk SCC relative to that in a freestall barn with fans and sprinklers. Their 2-yr study suggested that a tunnel-ventilated barn with evaporative cooling could work well, even in humid areas.

Open-shed barns attract pigeons and sparrows. To improve barn cooling and prevent epidemic disease, a tunnel-ventilated, water-padded freestall (TP) barn was built at the Livestock Research Institute (LRI) in Taiwan in 2004 and was evaluated in 2005. The maximum daytime air speed in the barn was $1.66 \mathrm{~m} / \mathrm{s}$ (air exchange rate of 2 times/min), and $\mathrm{RH}$ was $\geq 93.5 \%$ throughout the day. Cow RR and rectal $\mathrm{T}$ increased, and DMI and milk yield significantly decreased. Thus, the TP barn decreased daytime barn T and THI but increased the heat load of the cows (Shiao et al., 2009a,b). Low air speed and high RH were postulated to be the reasons for these responses. Because direct wetting and fan drying is the most effective and economical method for cooling cows (Hillman et al., 2005), the TP barn was remodeled by doubling the number of exhaust fans, applying sprinkler cooling, and increasing the outside shade. The feasibility of relieving heat stress was reevaluated with these new parameters and is reported in this paper.

\section{MATERIALS AND METHODS}

\section{Barn Treatment}

The trial was conducted in the LRI experimental farm from August to October 2006. Three barn cooling treatments were established in 2 adjacent barns, 1 in the conventional freestall barn and 2 in separate pens within 1 water-padded barn. A conventional freestall barn with fans and sprinkler cooling in the feed line $($ Fan+SP), commonly used in Taiwan, was used as the control. The Fan+SP barn had the following dimensions: a maximum roof height of $11.8 \mathrm{~m}$, side eaves of $3.4 \mathrm{~m}$, and a total area of $60 \mathrm{~m} \times 30 \mathrm{~m}$. Four fans $(1.5$ $\mathrm{kW}, 0.9-\mathrm{m}$ diameter, 3 blades, capacity $26,300 \mathrm{~m}^{3} / \mathrm{h}$ ), hung above the stalls and the feed line in the $12 \times 10-\mathrm{m}$ experimental pen, were operated $24 \mathrm{~h} / \mathrm{d}$. Based on the results of our previous sprinkler cooling (Lee et al., 1999) and night feeding studies (Lee et al., 2003), a line of sprinklers positioned above the headlock was turned on 8 times a day $(0800,0900,1000,1550,1650,1750$, 2200 , and $2300 \mathrm{~h}$ ) for 30-min rounds. Each round of sprinkling included six 5-min cycles with 1 min of water spraying. The quantity of water sprayed was $2.4 \mathrm{~L} /$ min per sprinkler. A detailed floor plan of the TP barn was described in an earlier report (Shiao et al., 2009a). The water-padded barn was constructed with an inside volume of $50 \mathrm{~m}$ long $\times 15 \mathrm{~m}$ wide $\times 2.5 \mathrm{~m}$ high. An L-shaped water pad $(20.2 \mathrm{~m}$ long $\times 0.45 \mathrm{~m}$ wide $\times 1.8$ $\mathrm{m}$ high) built from 3 layers of cubic honeycomb plastic was set at one side of the barn. At the other side of the wall, 16 exhaust fans were stationed that were identical to those used in the Fan+SP barn. A plastic curtain was hung at the 2 long sides to produce the tunnel effect. The airflow of the TP barn was controlled linearly by the Fancom F-Central system (Fancom AgriComputers, Panningen, the Netherlands). When barn $\mathrm{T}$ decreased below $26^{\circ} \mathrm{C}, 6$ fans operated to provide the minimum fresh air. Two fans per group were turned on for every $0.8^{\circ} \mathrm{C}$ increase in $\mathrm{T}$ until a maximum of 14 fans were operating. A water pump circulating wa- 
ter on the water-pad was also turned on when barn $\mathrm{T}$ $>26^{\circ} \mathrm{C}$. The cow allocation area $(42 \mathrm{~m}$ long $\times 11 \mathrm{~m}$ wide) was horizontally divided into 4 equal pens in the water-padded barn. The pen closest to the water pad was designated as the TP treatment, and the third pen nearer the fan wall and with same sprinkling program as that of Fan+SP barn was designated as the $\mathbf{T P}+\mathbf{S P}$ treatment. The facilities, including stall, water trough, headlock, and floor plan of these 3 experimental pens were similar. Twelve cows were housed in each pen, with the between 9.6 and $10 \mathrm{~m}^{2}$ of space per cow.

\section{Cow Management}

All animal use protocols were reviewed and approved by the Institutional Animal Care and Use Committee of the LRI. A $3 \times 3$ Latin square design with a 21 -d period was applied. Thirty-six lactating Holstein cows were assigned into 3 groups based on their milk yield, parity, DIM, and BW. The average conditions before the trial were $24.5 \pm 4.2 \mathrm{~kg}$ of milk yield, parity 1.5 $\pm 0.9,143 \pm 69 \mathrm{DIM}$, and $540 \pm 67 \mathrm{~kg}$ of BW. Each group contained 1 rumen-cannulated lactating cow. Cows were milked twice daily at 0500 and $1530 \mathrm{~h}$ and fed fresh TMR ad libitum at $0700 \mathrm{~h}$ (one-third of total) and $1500 \mathrm{~h}$ (two-thirds of total). This diet, which provided the nutritional requirements for $28 \mathrm{~kg}$ of milk yield (NRC, 2001), was composed of $11.1 \%$ corn silage, $20.6 \%$ napiergrass silage, $18.2 \%$ alfalfa hay, $15.3 \%$ silage of wet brewers grains and corn, $9.0 \%$ soybean hull pellet, and $25.8 \%$ corn-soybean meal grain mixture (DM basis). The diet contained $38.2 \% \mathrm{DM}, 16.2 \% \mathrm{CP}, 42.6 \%$ $\mathrm{NDF}$ and $1.54 \mathrm{Mcal}$ of $\mathrm{NE}_{\mathrm{L}} / \mathrm{kg}$ (DM basis). At the beginning and end of each period, BW was measured on 2 consecutive days at $0810 \mathrm{~h}$, before feeding.

\section{Barn Environment}

During the $63-\mathrm{d}$ trial period, barn $\mathrm{T}$ and $\mathrm{RH}$ were measured every $0.5 \mathrm{~h}$ by using a total of 12 Hobo Pro $\mathrm{RH} /$ Temp meters (Onset Computer Corp., Bourne, MA). Four thermometers were hung at the front and back of each experimental pen above the headlock and stall positions, $2 \mathrm{~m}$ above the ground. The measured data were transferred weekly onto a computer. The $4 \mathrm{~T}$ and $\mathrm{RH}$ readings from each pen were averaged first by time and then across days to plot the diurnal changes and to calculate THI $[\mathrm{THI}=9 / 5 \times \mathrm{T}+32-0.55$ $\times(1-\mathrm{RH}) \times(9 / 5 \times \mathrm{T}-26)$, with $\mathrm{T}$ in ${ }^{\circ} \mathrm{C}$ and $\mathrm{RH}$ in decimal] (NOAA, 1976). In this paper, THI is categorized in 4 levels, with THI $\leq 72,72<$ THI $\leq 78$, $78<$ THI $\leq 84$, and THI $>84$, representing cows that are comfortable, mildly stressed, moderately stressed, or seriously stressed, respectively (Armstrong, 1994;
Hahn et al., 2009). On each Monday and Friday, air speed was measured using a hot wire anemometer at the front and back of each pen, at a height of $1.5 \mathrm{~m}$ (cow-level), at 3 measuring locations (the TMR trough, feed line, and walk alley between stall rows) and 3 time points $(0830,1330$, and $1630 \mathrm{~h})$. Air speed data for each treatment and location were averaged first by time and then across days.

\section{Physiological Responses}

Individual cows' $\mathrm{RR}$ were counted for 2 periods of 30 $\mathrm{s}$ at 0300 and $1300 \mathrm{~h}$ for $2 \mathrm{~d}$ each period. The skin $\mathrm{T}$ of the central part of the neck and backside was measured simultaneously using an infrared thermometer (10-s reading period at a distance of $1 \mathrm{~m}$ ). To estimate the body core $\mathrm{T}$, individual vaginal $\mathrm{T}$ was measured every minute for $24 \mathrm{~h}$ by using a Hobo Water Temp Pro Data Logger (Onset Computer Corp.) inserted into a blank control internal drug release (CIDR, Eazi-Breed, Pfizer Animal Health, New York, NY) device. Before application, the progesterone in the device was thoroughly washed out with alcohol.

On 2 d during each 21-d period, 2 blood samples were collected from the jugular vein of each cow at 1300 h. The first sample was placed in a Monovette tube without heparin. After standing for $30 \mathrm{~min}$, the blood was centrifuged at $1,200 \times g$ for 15 min to obtain serum that was then frozen for future analyses, including tests for albumin (Alb), total protein, $\mathrm{Ca}, \mathrm{P}$, glucose, cholesterol (Chol), BUN, aspartate aminotransferase (AST), alanine aminotransferase (ALT), alkaline phosphatase (ALP), and lactate dehydrogenase (LDH). An autoanalyzer was subsequently used for these measurements (Data Pro Plus Random Access Clinical Analyzer, ThermoTrace, Victoria, Australia). The second blood sample was placed in a Blood Gas Monovette tube, left on ice and analyzed for blood $\mathrm{pH}$, partial pressure of $\mathrm{O}_{2}\left(\mathbf{p} \mathbf{O}_{2}\right)$, and partial pressure of $\mathrm{CO}_{2}\left(\mathbf{p} \mathbf{C O}_{\mathbf{2}}\right)$ using a $\mathrm{pH} /$ Blood Gas Analyzer (model 16200-06, Instrumentation Laboratory, Milan, Italy).

\section{Intake, Rumen Digestion, and Lactation Performance}

The amount of TMR offered, next-day refusals, and the actual number of cows in each group were recorded daily. Individual feed ingredients were sampled twice each period. Fresh TMR and next-day refusals were sampled daily during the last $10 \mathrm{~d}$ of each period for DMI measurement. All samples were stored at $-20^{\circ} \mathrm{C}$ before undergoing $48 \mathrm{~h}$ of drying at $55^{\circ} \mathrm{C}$ followed by pooling, grinding, and analyses. During the last $10 \mathrm{~d}$ of each period, cow activity was monitored by video. Two days were selected to count eating and resting activ- 
ity (e.g., number of cows eating/total cow number $x$ $100 \%$ ) every $10 \mathrm{~min}$. Continuous 48 -h rumen digestion was traced by rumen content sampling at $0700 \mathrm{~h}(0$ h, before a.m. feeding), 0900, 1100, 1300, 1500 ( 8 h, before p.m. feeding and milking), and 1800, 2000, 2200, 0000, 0230, and $0500 \mathrm{~h} \mathrm{(22} \mathrm{h,} \mathrm{before} \mathrm{a.m.} \mathrm{milking),}$ respectively. Rumen contents were filtered, and $\mathrm{pH}$ was measured immediately, and then contents were acidified with $50 \%$ sulfuric acid (50:1, vol/vol), and stored at $-20^{\circ} \mathrm{C}$. After centrifugation, the supernatant was analyzed for VFA concentration using gas chromatography with a flame ionization detector (CP-3800, Varian Inc., Walnut Creek, CA) and for $\mathrm{NH}_{3}-\mathrm{N}$ concentration using a spectrophotometer. Individual milk yields were recorded on a daily basis, and 2 a.m.-p.m. milk samples from each cow were sampled for milk composition analyses during each period (CombiFOSS 5000, Foss Analytical A/X, Slangerupgade, Denmark) in the Hsin-chu Branch of LRI.

\section{Statistical Analyses}

Relative environmental measures were expressed as the means \pm standard deviations. Bovine data, including $R R$, vaginal $T$, blood gases, serum biochemical metabolites, rumen $\mathrm{pH}, \mathrm{VFA}$ and $\mathrm{NH}_{3}-\mathrm{N}, \mathrm{BW}$, milk yield, and milk composition were analyzed using individual cows as the observation unit. Dry matter intake and intake activity were analyzed on a group basis. Data were analyzed using a general linear model in SAS (SAS Institute, 2003) with the Latin square model. Least squares means and variations were used to compare the cooling effect among 3 barn treatments at a significance level of $P<0.05$. If the $P$-value was close to 0.10 , the presence of a tendency was noted.

\section{RESULTS AND DISCUSSION}

\section{Barn Environment}

The pattern of diurnal changes of barn T, RH, and THI did not change between 2005 and 2006 (Shiao et al., 2009a). As expected, both the TP and TP+SP barns more effectively reduced daytime barn $\mathrm{T}$ (Figure 1A). The $2 \mathrm{TP}$ barns prevented barn $\mathrm{T}$ from exceeding $30^{\circ} \mathrm{C}$, but cows in the Fan $+\mathrm{SP}$ barn experienced $4.5 \mathrm{~h}$ per day of $\mathrm{T}>30^{\circ} \mathrm{C}$. The maximal barn $\mathrm{T}$ in the $\mathrm{TP}$ and $\mathrm{TP}+\mathrm{SP}$ barns were $3.7^{\circ} \mathrm{C}$ and $3.1^{\circ} \mathrm{C}$ lower than that in the Fan+SP barn, respectively (27.8 and 28.4 vs. $31.5^{\circ} \mathrm{C}$ ). The magnitude of reduction was consistent with the results of Smith et al. (2006a), who reported a decrease of $3.1^{\circ} \mathrm{C}$, and was greater than the $2.4^{\circ} \mathrm{C}$ decrease we noted in our 2005 study (Shiao et al., 2009a). Berman et al. (1985) suggested that the highest critical
$\mathrm{T}$ for dairy cows was approximately 25 to $26^{\circ} \mathrm{C}$. The length of the cool period (barn $\mathrm{T}<26^{\circ} \mathrm{C}$ ) in both TP barns increased by $35 \%$ ( $4.2 \mathrm{~h}$ per day) relative to that in the Fan+SP barn (16.2 vs. $12.0 \mathrm{~h}$ ).

The daytime $\mathrm{RH}$ inside the Fan+SP barn was inversely correlated with barn $\mathrm{T}$ : the lowest $\mathrm{RH}$ of $68.7 \%$ was observed at the hottest time of day (noon). The $\mathrm{RH}$ in the Fan+SP barn was also close to $100 \%$ for $69 \%$ of each day $(16.5 \mathrm{~h})$, with higher levels of humid-
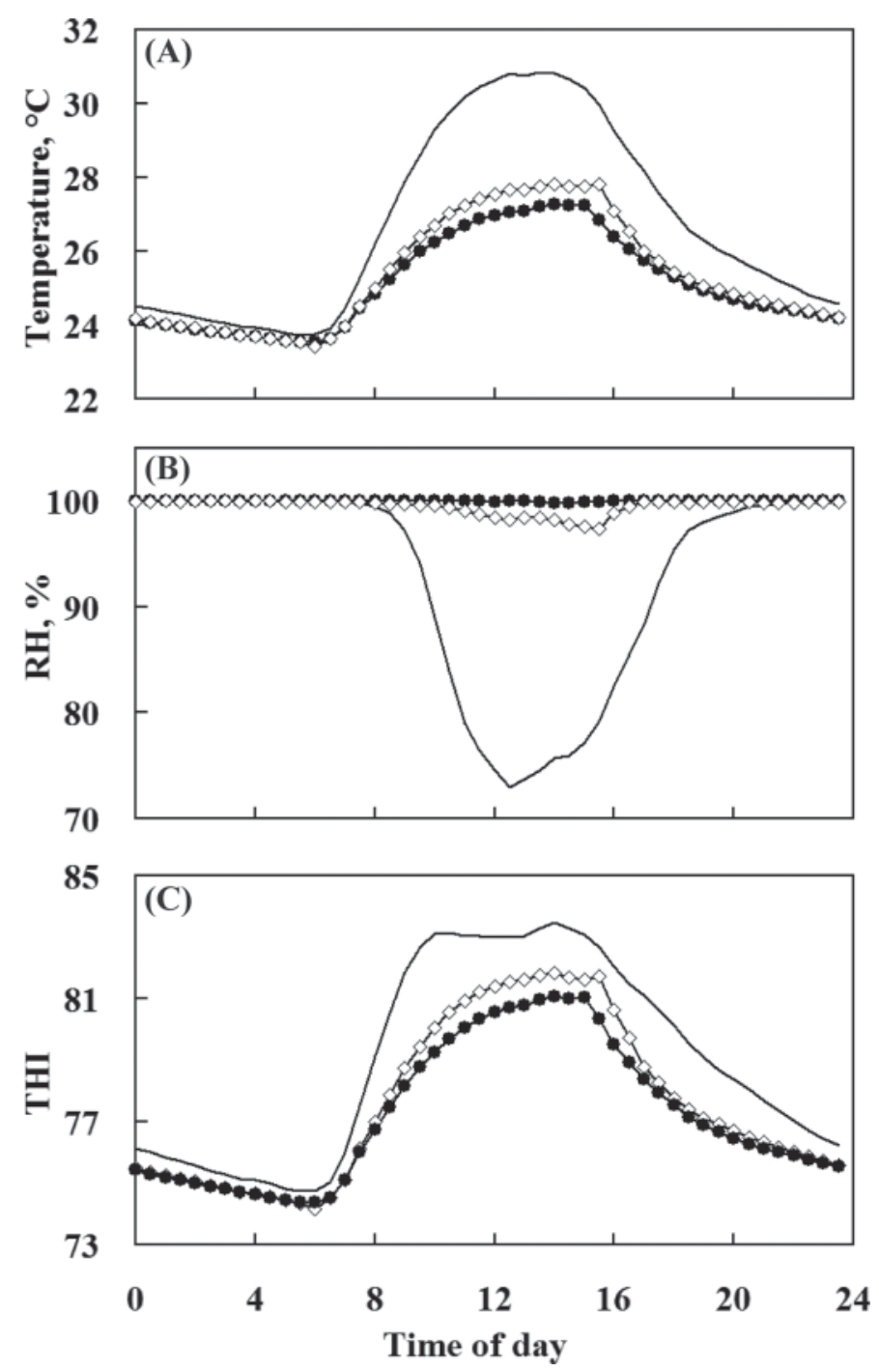

Figure 1. Effect of the tunnel-ventilated, water-padded barn environment on (A) barn diurnal temperature (T), (B) relative humidity $(\mathrm{RH})$, and $(\mathrm{C})$ temperature-humidity index (THI) changes. The barn environments compared included the Fan+SP barn (solid line; freestall barn with fans and sprinklers, control), TP barn ( $\bullet$ tunnel-ventilated, water-padded barn), and TP+SP barn $(\diamond$; TP barn with sprinklers) during the hot, humid season (August to October) at the Livestock Research Institute of Taiwan during 2006. Barn T and RH were recorded every 30 min by Hobo Pro $\mathrm{RH} /$ Temp meters (Onset Computer Corp., Bourne, MA). THI $=9 / 5 \times \mathrm{T}+32-0.55 \times(1-\mathrm{RH}) \times(9 / 5$ $\times \mathrm{T}-26$ ), with $\mathrm{T}$ in ${ }^{\circ} \mathrm{C}$ and $\mathrm{RH}$ in decimal (NOAA, 1976). Each point represents the average of 63 daily measurements. 
ity predominating at night. A persistently high $\mathrm{RH}$, $>96 \%$ during the entire day, was found in both the $\mathrm{TP}$ and $\mathrm{TP}+\mathrm{SP}$ barns (Figure 1B). Consistent with this finding, other studies conducted in humid areas have shown high $\mathrm{RH}$ in water-padded barns (Smith et al., 2006a; Brouk et al., 2010). These findings have stimulated discussion regarding the appropriateness of water padding in humid regions. Many studies have supported the observation that humidity affects heat stress more strongly than does temperature. Humidity affects the critical $\mathrm{T}$ at which cows feel comfortable. At low $\mathrm{RH}$, the critical $\mathrm{T}$ can be as high as $27^{\circ} \mathrm{C}$; at higher $\mathrm{RH}$, the critical $\mathrm{T}$ decreases to $22^{\circ} \mathrm{C}$, and cows begin to suffer heat stress at this relatively low temperature (Armstrong, 1994; West, 2003). High humidity inhibits sweating. Maia et al. (2005b) reported that the sweating rate decreased from 500 to $60 \mathrm{~g}$ of $\mathrm{H}_{2} \mathrm{O} / \mathrm{m}^{2} \mathrm{~h}$ when $\mathrm{RH}$ increased from 30 to $90 \%$. Importantly, the severity of high humidity can be partially mitigated by high air speed. When the air speed crossing a cow's body surface increases from 0.2 to $0.9 \mathrm{~m} / \mathrm{s}$, the animal's sweating rate increases from 75 to $350 \mathrm{~g}$ of $\mathrm{H}_{2} \mathrm{O} / \mathrm{m}^{2} \mathrm{~h}$ (Hillman et al., 2001). However, if the air speed used for mist cooling is not high enough, small water droplets accumulate on the cows' surface hair and form an insulating barrier that prevents heat dissipation (Hahn, 1985). Thus, air speed plays an influential role in determining the utility of water-padded barns.

In this study, 14 fans in the water-padded barn were operated during most daytime hours. The average daytime cow-level air speed reached $2.38 \mathrm{~m} / \mathrm{s}$ in the TP barn (Table 2). In the TP+SP barn, which was located in the third pen from the air inlet, the air speed decreased to $2.06 \mathrm{~m} / \mathrm{s}$. The highest calculated daytime air exchange rate in the barn was 3.2 times/min. The greater number of fans in the newer (2006) water-padded barns increased air speed and air exchange rates relative to the TP barn constructed in $2005(1.66 \mathrm{~m} / \mathrm{s}$ and 2.0 times/min, respectively). Without the tunnel effect, the air speed in the Fan+SP barn reached only $1.23 \mathrm{~m} / \mathrm{s}(52 \%$ and $60 \%$ of that in the TP and $\mathrm{TP}+\mathrm{SP}$ barns, respectively). At night, barn $\mathrm{T}$ in the 2 water-padded barns was $<26^{\circ} \mathrm{C}$ (Figure 1A). At this temperature, the computer only activated 6 fans. The air speed and air exchange rate were estimated to be only $1.17 \mathrm{~m} / \mathrm{s}$ and 1.4 times/min, respectively. The effectiveness of cooling the cow by direct wetting depends on air speed. Bray et al. (1992) and Gooch and Timmons (2000) recommended using an air velocity of at least 2 to $3 \mathrm{~m} / \mathrm{s}$ over the cows' backs with a fan and sprinkler system for a freestall barn. Chastain and Turner (1994) suggested that the air speed required to dry soaked cows in a humid area was 2.9 to $4.0 \mathrm{~m} / \mathrm{s}$. In this study, the daytime air speed of 2.38 to $2.06 \mathrm{~m} / \mathrm{s}$ in water-padded barns was within or below the recommended range. However, the nighttime air speed of 1.17 $\mathrm{m} / \mathrm{s}$ was far below the recommended air speed, and this factor might seriously restrict cow heat dissipation. We believe that the significantly increased panting rate and skin $\mathrm{T}$ of cows in water-padded barns during the cool night was a direct cow response of this low air speed.

Temperature-humidity index is commonly used as an indicator of cow heat stress, but its appropriateness has been questioned. It was originally designed for dry environments (Armstrong, 1994). Sprinklers and fans relieved heat stress effectively but did not decrease environmental THI. However, after comparing the T, $\mathrm{RH}$, wind speed, and THI with Holstein cow rectal temperatures in a subtropical environment, Dikmen and Hansen (2009) suggested that THI would be a good predictor for heat stress. In this study, THI values supported the argument that none of the 3 barn cooling methods could offer a comfortable environment for dairy cows. Cows always lived under mild $(72<$ THI $\leq 78$, nighttime) to moderate $(78<\mathrm{THI} \leq 84$, daytime $)$ heat stress (Figure 1C).

\section{Physiological Responses}

Respiration Rate and Body Temperature. Four cows were removed from the trial because of mastitis or

Table 2. Air speed (m/s; mean $\pm \mathrm{SD})$ in 3 experimental barns occupied by lactating Holstein cows in Taiwan during $2006^{1}$

\begin{tabular}{lcccc}
\hline & & \multicolumn{3}{c}{ Barn $^{2}$} \\
\cline { 3 - 5 } Time & Days & TP & TP + SP \\
\cline { 3 - 5 } & 15 & $1.18 \pm 0.11$ & $2.22 \pm 0.60$ & $1.80 \pm 0.49$ \\
$1330 \mathrm{~h}$ & 16 & $1.23 \pm 0.14$ & $2.57 \pm 0.27$ & $2.23 \pm 0.22$ \\
$1630 \mathrm{~h}$ & 16 & $1.29 \pm 0.11$ & $2.34 \pm 0.37$ & $2.13 \pm 0.40$ \\
Average & 15 & $1.23 \pm 0.12$ & $2.38 \pm 0.45$ & $2.06 \pm 0.42$ \\
\hline
\end{tabular}

${ }^{1}$ Air speed was measured with a hot wire anemometer every Monday and Friday in 3 fully occupied barns from August to October, 2006. Values shown are averages of measurements taken at the front and back of each pen and from the TMR trough, intake lane, and alleyway between stall rows at $1.5 \mathrm{~m}$ elevation.

${ }^{2} \mathrm{Fan}+\mathrm{SP}$ barn $=$ freestall barn with fans and sprinklers $($ control); TP barn $=$ tunnel-ventilated, water-padded barn; $\mathrm{TP}+\mathrm{SP}$ barn $=\mathrm{TP}$ barn with sprinklers. 
drying. The cows' RR was positively correlated with air $\mathrm{T}$ (Hahn et al., 1997). Cow RR begins to increase when the ambient $\mathrm{T}$ reaches $19^{\circ} \mathrm{C}$, and sweating commences at $25^{\circ} \mathrm{C}$ (Hahn et al., 1997; Maia et al., 2005a,b). Under heat stress conditions, the cows' skin $\mathrm{T}$ was closely related to their RR (Collier et al., 2006). At $1300 \mathrm{~h}$, all cows panted at an average of 54 times per min (Figure $2 \mathrm{~A})$. Cows in the $\mathrm{TP}$ and $\mathrm{TP}+\mathrm{SP}$ barns had higher $\mathrm{RR}$ at $0300 \mathrm{~h}$ compared with those in the Fan+SP barn (53 vs. 42 times/min; $P<0.001$ ). Respiration rate responses varied across cooling conditions. Cows in the Fan+SP barn panted harder when barn $\mathrm{T}$ increased, but cows in the 2 water-padded barns panted hard even in the cool early morning. Skin T measured at $0300 \mathrm{~h}$ was correlated with $\mathrm{RR}$, with cows in $\mathrm{TP}$ and $\mathrm{TP}+\mathrm{SP}$ barns having higher skin $\mathrm{T}$ than those in the Fan+SP barn (Figure 2B and 2C). The back skin T of cows in these 3 barns was $28.92,29.27$, and $28.31^{\circ} \mathrm{C}$, respectively $(P<0.001)$ in $\mathrm{TP}, \mathrm{TP}+\mathrm{SP}$, and Fan $+\mathrm{SP}$. Skin T increased with increasing barn T. At $1300 \mathrm{~h}$, the back skin $\mathrm{T}$ readings were highest in the Fan+SP barn, intermediate in the $\mathrm{TP}+\mathrm{SP}$ barn, and lowest in the TP barn with values of $32.48,31.60$, and $31.04^{\circ} \mathrm{C}$, respectively $(P<0.001)$. This daytime skin $\mathrm{T}$ trend correlated well with the barn $\mathrm{T}$ and cow heat load.

Regardless of when they were measured (cool early morning or during the hot noontime), cow RR measured in this trial were markedly higher than the 26 to 35 breaths/min recommended for comfortable cows (Reece, 1993). The high RR response corroborated the barn environment measurement results and confirmed that the 3 cooling treatments still left cows in a condition of heat stress. Around $0300 \mathrm{~h}$, the 3 barn environments were similar (Figure 1), but the RR and skin $\mathrm{T}$ from cows in TP and TP+SP barns were significantly higher. This phenomenon suggested that factors other than $\mathrm{T}$ and RH influenced the cows' heat load. Air speed is definitely a contributing factor. The nighttime air speed in water-padded barns was only $50 \%$ $(1.17 \mathrm{~m} / \mathrm{s})$ of that in the daytime, and it was much lower than the recommended 2 to $3 \mathrm{~m} / \mathrm{s}$ (Bray et al., 1992; Gooch and Timmons, 2000). The effectiveness of intrinsic sweating or external sprinkling was reduced due to this significantly lower air speed (Hillman et al., 2001). Cows were therefore forced to pant hard to dissipate body heat during the cool night. Thus, the $26^{\circ} \mathrm{C} \mathrm{T}$ setting that controls the minimum number of operating fans should be lowered to increase the nighttime air speed. The type of barn might also affect the heat stress mitigation. When the air T cools, cows and the surrounding barn structure surface can dissipate accumulated heat by radiation into the cool night air (Hahn, 1994). In a closed, tunnel-ventilated barn, this radiant heat exchange is likely to be restricted.
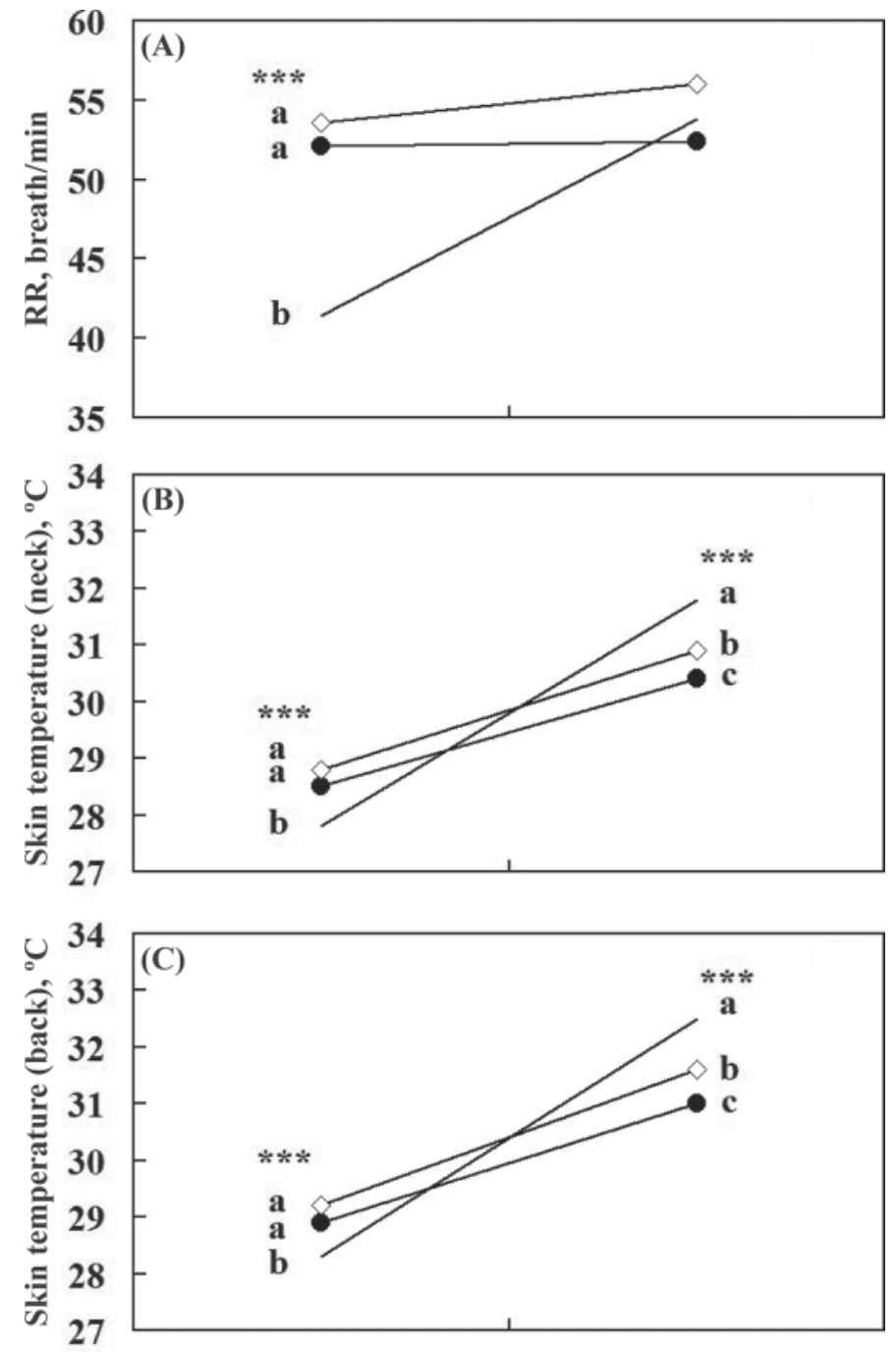

3 a.m.

Time measured

Figure 2. Effect of the tunnel-ventilated, water-padded barn environment on $(A)$ respiration rates $(\mathrm{RR})$ and skin temperature $(\mathrm{T})$ of the (B) neck and (C) back of lactating Holstein cows. The RR and skin $\mathrm{T}$ were measured at 0300 and $1300 \mathrm{~h}$ on $2 \mathrm{~d}$ during the last 10 d of each period from 29 cows raised in the Fan+SP barn (solid line; freestall barn with fans and sprinklers, control), TP barn (৫; tunnelventilated, water-padded barn), and TP $+\mathrm{SP}$ barn $(\diamond ; \mathrm{TP}$ barn with sprinklers) in a $3 \times 3$ Latin square design. Cows raised in the TP and $\mathrm{TP}+\mathrm{SP}$ barns had higher RR and neck and back skin $\mathrm{T}$ at $0300 \mathrm{~h}$ than those raised in the Fan+SP barn. At $1300 \mathrm{~h}$, the neck and back skin $\mathrm{T}$ differed among the 3 barn treatments $($ Fan $+\mathrm{SP}>\mathrm{TP}+\mathrm{SP}>\mathrm{TP}$ barn). Data points with different letters $(\mathrm{a}-\mathrm{c})$ differ $(* * * P<0.001)$.

Unlike the more dynamic (and indicative of current environment) $\mathrm{RR}$ and skin $\mathrm{T}$, vaginal $\mathrm{T}$ representing body core $\mathrm{T}$ was measured. The highest vaginal $\mathrm{T}$ of cows raised in the 3 environments was similar $\left(39.59^{\circ} \mathrm{C}\right.$; Table 3 ). The diurnal variation in vaginal $\mathrm{T}$ change was very interesting (Figure 3). The vaginal $\mathrm{T}$ of cows in the TP group was persistently high $\left(38.9\right.$ to $\left.39.2^{\circ} \mathrm{C}\right)$. The 
maximal reduction of $0.15^{\circ} \mathrm{C}$ occurred after 2 milkings. The cows in the TP+SP condition, although housed in the same building, reacted differently. Their diurnal variation resembled that of cows in the Fan+SP barn. Cow vaginal $\mathrm{T}$ measurements from the $2 \mathrm{SP}$ treatments were reduced by 0.4 to $0.6^{\circ} \mathrm{C}$ after 2 milkings and, more importantly, after initiation of sprinkler cooling. This phenomenon explicitly illustrates the effectiveness of wet and fan cooling. Hillman et al. (2005) further reported that, when standing cows received $17 \mathrm{~min}$ of spraying and fan, vaginal $\mathrm{T}$ decreased at a rate of $-0.5^{\circ} \mathrm{C} / \mathrm{h}$. If the spray and fan treatment was extended to $64 \mathrm{~min}$, the reduction rate of vaginal $\mathrm{T}$ increased to $-1.02^{\circ} \mathrm{C} / \mathrm{h}$. Berman (2010) also found that, during 7 spray and fan cycles, the skin $\mathrm{T}$ of wet skin decreased more quickly than that of dry skin. Israeli researchers have emphasized multi-cooling methods using spraying and fans in the holding area for high-yielding cows (Flamenbaum and Ezra, 2007). Results from this study have shown that spray and fan methods can efficiently increase heat evaporation even in an extremely humid environment (RH near 100\% in the water-padded barn). This finding was consistent with research conducted in Kansas, Florida, and Thailand, which demonstrated that a combination of tunnel ventilation, evaporative cooling, and spraying significantly reduced cows' RR and body T (Brouk et al., 2010).

Blood Gas. Heat stress affects the physiological acid-base balance (West et al., 1992). When heat load increases, cows increase heat evaporation from the upper respiratory tract by panting more frequently. However, panting lowers blood $\mathrm{CO}_{2}$ and results in respiratory alkalosis, revealed in blood gas analysis by decreased $\mathrm{pCO}_{2}$, decreased $\mathrm{HCO}_{3}{ }^{-}$level, and increased pH (Sanchez et al., 1994; Calamari et al., 2007). In

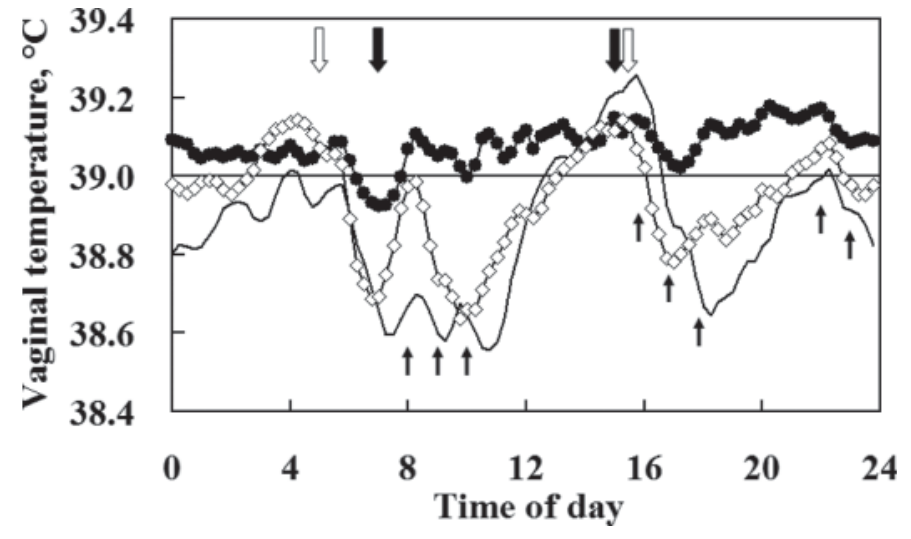

Figure 3. Effect of the tunnel-ventilated, water-padded barn environment on the diurnal vaginal temperature changes of lactating Holstein cows. Cows were raised in the Fan $+\mathrm{SP}$ barn (solid line; freestall barn with fans and sprinklers, control), TP barn (৫; tunnelventilated, water-padded barn), and $\mathrm{TP}+\mathrm{SP}$ barn $(\diamond$; TP barn with sprinklers) in a $3 \times 3$ Latin square design. Vaginal temperature was taken every minute by the Hobo Water Temp Pro Data Logger (Onset Computer Corp., Bourne, MA) fixed in a blank control internal drug release (CIDR, Eazi-Breed, Pfizer Animal Health, New York, NY) device and inserted into the vagina for $24 \mathrm{~h}$. Milking (downward white arrow) and spray cooling (thin black arrows) effectively decreased the vaginal temperature of cows in the $\mathrm{Fan}+\mathrm{SP}$ and $\mathrm{TP}+\mathrm{SP}$ barns. The 2 feeding times are indicated by a downward black arrow. The vaginal temperature of cows in the TP barn decreased only after milking and to a much smaller degree. Each point represents an average of 32 cows per group.

our 2005 study of cows in the TP barn, low air speed and high humidity caused a serious heat burden, resulting in respiratory alkalosis (Shiao et al., 2009a). In contrast, all cows in this study had similar blood $\mathrm{pCO}_{2}$, although the blood $\mathrm{pH}$ of cows in the TP barn tended to be lower $(P=0.08$; Table 4$)$. This implied that the increased air speed and sprinkler cooling in the water-padded barn applied in this study helped

Table 3. Effect of the tunnel-ventilated, water-padded barn environment on the diurnal vaginal temperature changes of lactating Holstein cows in Taiwan during $2006^{1}$

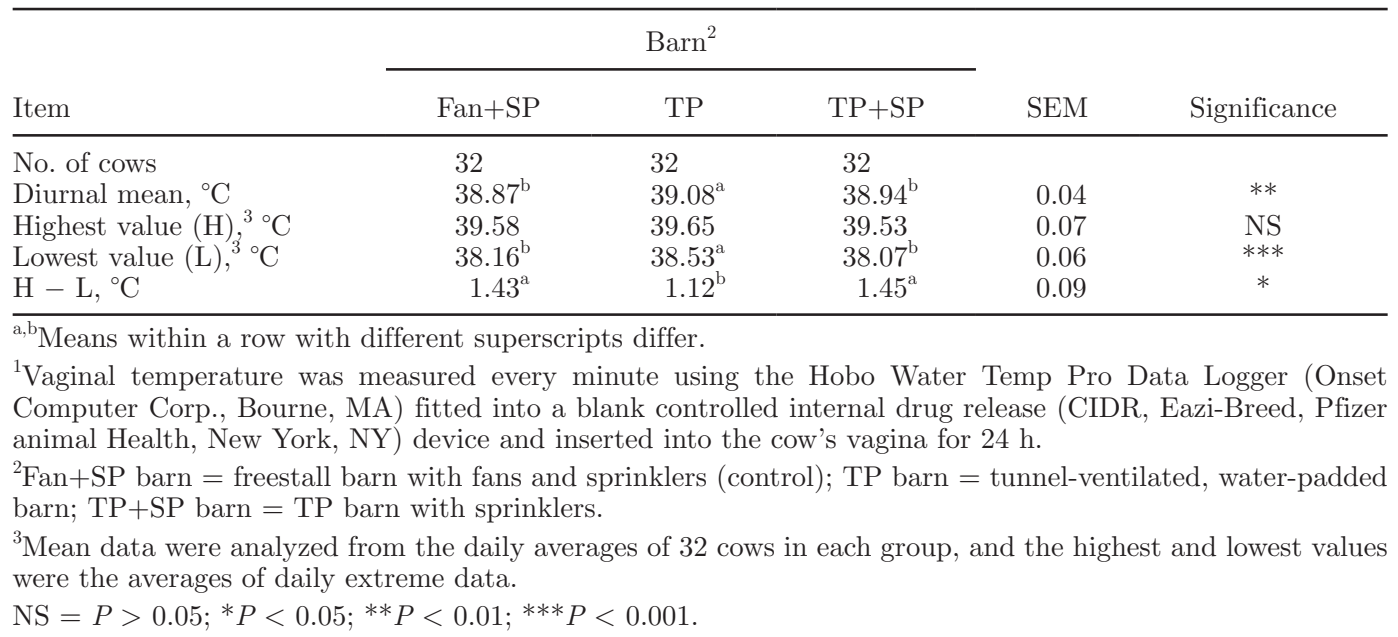


Table 4. Effect of the tunnel-ventilated, water-padded barn environment on blood gases and serum biochemical metabolites of lactating Holstein cows in Taiwan during $2006^{1}$

\begin{tabular}{lccccc}
\hline & \multicolumn{5}{c}{ Barn $^{3}$} \\
\cline { 2 - 3 } Item $^{2}$ & Fan+SP & TP & TP+SP & SEM & $\begin{array}{c}\text { Significance } \\
(P \text {-value })\end{array}$ \\
\cline { 2 - 4 } No. of cows & 32 & 32 & 32 & & \\
Blood pH & 7.405 & 7.397 & 7.404 & 0.003 & 0.08 \\
$\mathrm{pCO}_{2}, \mathrm{mmHg}$ & 42.3 & 42.8 & 42.6 & 0.4 & NS \\
$\mathrm{pO}_{2}, \mathrm{mmHg}$ & $31.5^{\mathrm{a}}$ & $30.5^{\mathrm{b}}$ & $30.4^{\mathrm{b}}$ & 0.3 & $*$ \\
Total protein, g/L & $69.5^{\mathrm{b}}$ & $70.6^{\mathrm{ab}}$ & $71.6^{\mathrm{a}}$ & 0.5 & $*$ \\
Albumin, $\mu \mathrm{mol} / \mathrm{L}$ & 0.49 & 0.49 & 0.49 & 0.01 & $\mathrm{NS}$ \\
$\mathrm{BUN}, \mathrm{mmol} / \mathrm{L}$ & 7.28 & 7.56 & 7.40 & 0.11 & $\mathrm{NS}$ \\
Ca, mmol/L & 2.16 & 2.18 & 2.18 & 0.02 & NS \\
$\mathrm{P}, \mathrm{mmol} / \mathrm{L}$ & $1.94^{\mathrm{b}}$ & $2.08^{\mathrm{a}}$ & $1.95^{\mathrm{b}}$ & 0.03 & $*$ \\
Glucose, mmol/L & 2.34 & 2.28 & 2.34 & 0.05 & NS \\
Cholesterol, mmol/L & $6.47^{\mathrm{a}}$ & $6.21^{\mathrm{ab}}$ & $6.10^{\mathrm{b}}$ & 0.09 & $*$ \\
ALP, U/L & $43.5^{\mathrm{a}}$ & $38.8^{\mathrm{b}}$ & $41.4^{\mathrm{ab}}$ & 1.0 & $* *$ \\
AST, U/L & 81.7 & 86.2 & 85.7 & 1.6 & 0.10 \\
ALT, U/L & $42.9^{\mathrm{a}}$ & $40.6^{\mathrm{b}}$ & $41.5^{\mathrm{b}}$ & 0.4 & $* * *$ \\
LDH, U/L & 672 & 690 & 693 & 19 & NS \\
\hline
\end{tabular}

${ }^{\mathrm{a}, \mathrm{b}}$ Means within a row with different superscripts differ.

${ }^{1}$ Blood samples from each individual cow were taken twice at $1300 \mathrm{~h}$ from the jugular vein each period in a 3 $\times 3$ Latin square design.

${ }^{2} \mathrm{pCO}_{2}=$ partial pressure of carbon dioxide; $\mathrm{pO}_{2}=$ partial pressure of oxygen; $\mathrm{ALP}=$ alkaline phosphatase; $\mathrm{AST}=$ aspartate aminotransferase; ALT $=$ alanine aminotransferase $\mathrm{LDH}=$ lactate dehydrogenase.

${ }^{3} \mathrm{Fan}+\mathrm{SP}$ barn $=$ freestall barn with fans and sprinklers $($ control $) ; \mathrm{TP}$ barn $=$ tunnel-ventilated, water-padded barn; TP $+\mathrm{SP}$ barn $=\mathrm{TP}$ barn with sprinklers.

NS $=P>0.05 ; * P<0.05 ; * * P<0.01 ; * * P<0.001$.

heat dissipation. Blood $\mathrm{pO}_{2}$ was higher in cows in the Fan+SP barn, an effect that might be related to the barn type. Sabuncuoglu et al. (2008) reported that, during the cold season, the higher airflow of an openshed barn contributed to a higher blood $\mathrm{pO}_{2}$ relative to a closed-type barn.

Serum Metabolite. Serum metabolites have been studied to identify markers of bovine heat stress. The pattern of serum metabolites was consistent between our 2005 and 2006 studies. The serum Alb, BUN, Ca, glucose, AST, and LDH of cows in the Fan+SP and TP barns were similar. Cows in the TP barn had higher serum total protein and $\mathrm{P}$ and lower Chol, ALP, and ALT. The serum metabolites of cows in the TP+SP barn resembled the trend of cows in the TP barn, with the exception of low serum P levels (Table 4).

Table 5. Effect of the tunnel-ventilated, water-padded barn environment on the intake and resting activity of lactating Holstein cows in Taiwan during $2006^{1}$

\begin{tabular}{|c|c|c|c|c|c|}
\hline \multirow[b]{2}{*}{ Item } & \multicolumn{3}{|c|}{ Barn $^{2}$} & \multirow[b]{2}{*}{ SEM } & \multirow{2}{*}{$\begin{array}{c}\text { Significance } \\
(P \text {-value })\end{array}$} \\
\hline & $\mathrm{Fan}+\mathrm{SP}$ & $\mathrm{TP}$ & $\mathrm{TP}+\mathrm{SP}$ & & \\
\hline No. of observations & 3 & 3 & 3 & & \\
\hline Time spent lying, $\mathrm{h} / \mathrm{d}$ & 12.2 & 11.5 & 12.3 & 0.3 & NS \\
\hline Time spent eating, $\mathrm{h} / \mathrm{d}$ & 5.7 & 4.8 & 5.1 & 0.2 & NS \\
\hline \multicolumn{6}{|l|}{ Percentage of cows eating } \\
\hline 0730 to $0930 \mathrm{~h}$ (a.m. feeding) & 53.9 & 42.9 & 47.7 & 6.4 & NS \\
\hline 0930 to $1130 \mathrm{~h}$ & 23.6 & 21.9 & 24.8 & 0.5 & 0.10 \\
\hline 1130 to $1430 \mathrm{~h}$ & $12.6^{\mathrm{a}}$ & $6.3^{\mathrm{b}}$ & $8.5^{\mathrm{ab}}$ & 0.7 & $*$ \\
\hline 1500 to 1730 h (p.m. feeding) & 67.7 & 50.7 & 61.3 & 3.1 & 0.11 \\
\hline 1730 to $2100 \mathrm{~h}$ & 21.0 & 22.1 & 23.8 & 2.2 & NS \\
\hline 2100 to $0000 \mathrm{~h}$ & 17.0 & 19.2 & 20.1 & 2.5 & NS \\
\hline 0000 to $0500 \mathrm{~h}$ & 9.8 & 11.2 & 7.2 & 0.8 & NS \\
\hline 0500 to $0730 \mathrm{~h}$ & 22.2 & 13.4 & 14.8 & 3.9 & NS \\
\hline
\end{tabular}

$\overline{\mathrm{a}, \mathrm{b}}$ Means within a row with different superscripts differ.

${ }^{1}$ Thirty-six cows were randomly assigned into 3 barn treatments in a $3 \times 3$ Latin square design and group-fed. Two periods of $24 \mathrm{~h}$ of cow behavior were recorded by video and counted every $10 \mathrm{~min}$. The percentage of cows eating was calculated from this data.

${ }^{2}$ Fan + SP barn $=$ freestall barn with fans and sprinklers $($ control $) ;$ TP barn $=$ tunnel-ventilated, water-padded barn; $\mathrm{TP}+\mathrm{SP}$ barn $=\mathrm{TP}$ barn with sprinklers.

$\mathrm{NS}=P>0.05 ;{ }^{*} P<0.05$. 


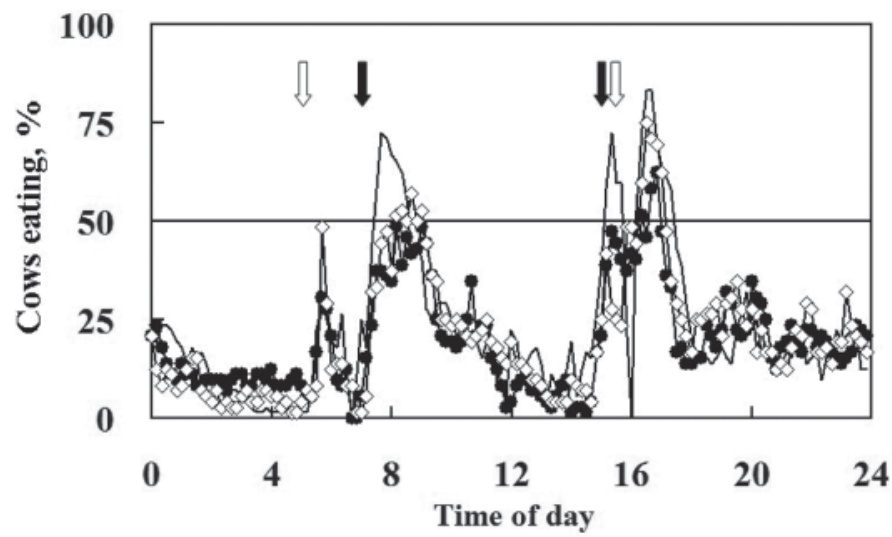

Figure 4. The effect of the tunnel-ventilated, water-padded barn environment on the intake activity of lactating Holstein cows. A total of 36 cows were group-fed in the Fan+SP barn (solid line; freestall barn with fans and sprinklers, control), TP barn (- tunnel-ventilated, water-padded barn), and $\mathrm{TP}+\mathrm{SP}$ barn $(\diamond$; TP barn with sprinklers) in a $3 \times 3$ Latin square design. Cow activity was recorded by video and counted every $10 \mathrm{~min}$ for two 24 -h periods. The number of cows eating was calculated as the percentage of each group. The peak intake activity appeared soon after fresh TMR was offered (black arrows) and decreased to $0 \%$ when cows left for milking (white arrows).

Serum protein and BUN reportedly increase when air $\mathrm{T}$ increases from 18 to $32^{\circ} \mathrm{C}$ (Koubková et al., 2002). In this study, the serum total protein of cows in both water-padded barns increased, but Alb and BUN were similar to those of cows in the Fan+SP barn. Other studies found that the hot season caused lower plasma glucose, Chol, and ALP in Holstein cows (Abeni et al., 2007; Calamari et al., 2007). In our study, serum Chol and ALP were relatively decreased in both waterpadded barns, but glucose level was not. Both AST and ALT are involved in the transfer of amino groups. The ALT activity of high-producing cows decreases with increasing air T (Koubková et al., 2002). In our study, ALT was lower in cows housed in water-padded barns, but AST activity tended to be higher $(P=0.10)$. The serum $\mathrm{P}$ level of cows in the TP barn was higher than that in the $2 \mathrm{SP}$ groups, which is consistent with previous results (Shiao et al., 2009a). In the Sanchez et al. (1994) study, phosphorus absorption decreased by $50 \%$ in heat-stressed cows. It was thus postulated that lower absorption led to accumulation of $\mathrm{P}$ in the serum and decreased the $\mathrm{P}$ available for cellular ALP synthesis. The high serum $\mathrm{P}$ and low serum ALP in cows in the TP barn support this hypothesis. However, the low serum $\mathrm{P}$ and intermediate ALP activity of cows in the $\mathrm{TP}+\mathrm{SP}$ barn seem to indicate lower heat stress relative to the TP barn. Further research is required to verify this hypothesis. Overall, these serum analyses did not clearly indicate the heat stress level associated with the 3 cooling treatments investigated in this study.
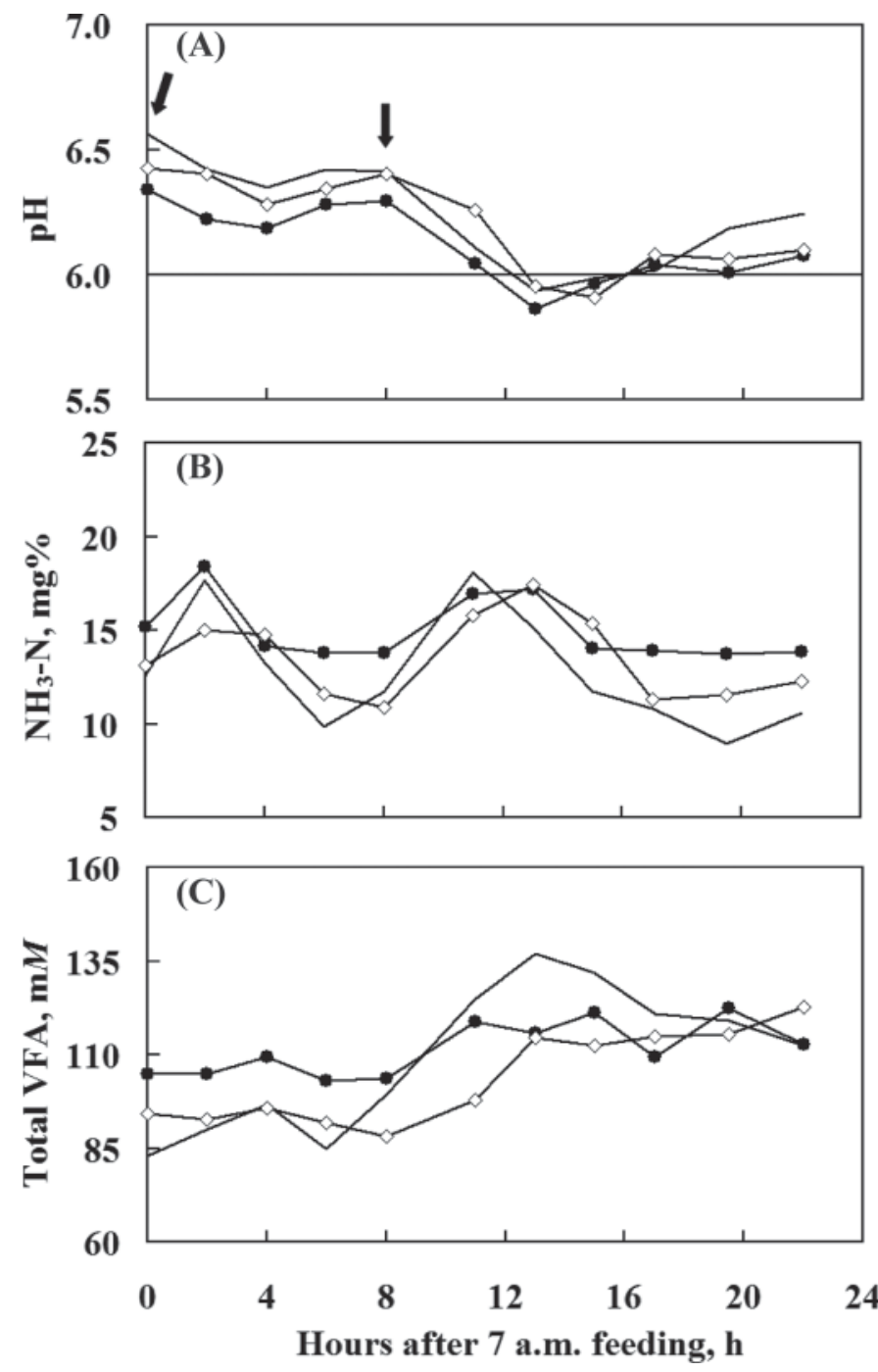

Figure 5. Effect of the tunnel-ventilated, water-padded barn environment on the diurnal rumen $\mathrm{pH}, \mathrm{NH}_{3}-\mathrm{N}$, and VFA concentrations of lactating Holstein cows. Three rumen-cannulated cows were raised in the Fan+SP barn (solid line; freestall barn with fans and sprinklers, control), TP barn ( and $\mathrm{TP}+\mathrm{SP}$ barn $(\diamond ; \mathrm{TP}$ barn with sprinklers) in a $3 \times 3$ Latin square design. Two consecutive 24 -h rumen content samplings were conducted each period. Rumen digestion became active after 2 fresh TMR offerings (arrows). Rumen $\mathrm{NH}_{3}-\mathrm{N}$ concentration was more stable and tended to be higher $(P=0.06)$ in cows raised in the TP barn. The diurnal weighted average, highest, and lowest values of rumen $\mathrm{pH}$ and total VFA were similar among barn treatments.

\section{Intake, Rumen Digestion, and Lactation Performance}

Intake Activity. Quantification of recorded behaviors revealed that cows in the 3 barn treatments spent similar amounts of time per day eating ( 4.8 to $5.7 \mathrm{~h}$ ) and lying down (11.5 to $12.3 \mathrm{~h}$; Table 5 ). Cow comfort studies recommend that lactating cows should eat for 3 to $5 \mathrm{~h}$ and rest for 12 to $14 \mathrm{~h} / \mathrm{d}$ (Grant, 2007). Relative to the ideal condition, cows spent more time eating and 
Table 6. Effect of the tunnel-ventilated, water-padded barn environment on the lactation performance of lactating Holstein cows in Taiwan during $2006^{1}$

\begin{tabular}{|c|c|c|c|c|c|}
\hline \multirow[b]{2}{*}{ Item } & \multicolumn{3}{|c|}{ Barn $^{2}$} & \multirow[b]{2}{*}{ SEM } & \multirow{2}{*}{$\begin{array}{c}\text { Significance } \\
(P \text {-value })\end{array}$} \\
\hline & $\mathrm{Fan}+\mathrm{SP}$ & $\mathrm{TP}$ & $\mathrm{TP}+\mathrm{SP}$ & & \\
\hline No. of observations & 3 & 3 & 3 & & \\
\hline DMI, kg & $18.5^{\mathrm{b}}$ & $18.8^{\mathrm{a}}$ & $18.8^{\mathrm{a}}$ & 0.03 & $*$ \\
\hline No. of cows observed & 32 & 32 & 32 & & \\
\hline Initial BW, kg & 546 & 549 & 549 & 2 & NS \\
\hline BW gain, $\mathrm{kg} / \mathrm{d}$ & 0.40 & 0.23 & 0.32 & 0.10 & NS \\
\hline Milk yield, $\mathrm{kg} / \mathrm{d}$ & 24.7 & 25.0 & 25.4 & 0.2 & 0.10 \\
\hline $4 \% \mathrm{FCM}, \mathrm{kg} / \mathrm{d}$ & 24.9 & 25.1 & 25.4 & 0.3 & NS \\
\hline Milk fat, $\%$ & 4.06 & 4.05 & 4.02 & 0.05 & NS \\
\hline Milk protein, $\%$ & $3.18^{\mathrm{a}}$ & $3.18^{\mathrm{a}}$ & $3.11^{\mathrm{b}}$ & 0.02 & $*$ \\
\hline Milk lactose, \% & 4.74 & 4.73 & 4.75 & 0.02 & NS \\
\hline Milk total solids, $\%$ & 12.67 & 12.67 & 12.58 & 0.05 & NS \\
\hline $\mathrm{SCC}, \times 10^{4} / \mathrm{mL}$ & 127 & 73 & 58 & 25 & 0.13 \\
\hline
\end{tabular}

${ }^{\mathrm{a}, \mathrm{b}}$ Means within a row with different superscripts differ.

${ }^{1}$ Thirty-six cows were randomly assigned into 3 barn treatments in a $3 \times 3$ Latin square design and group-fed. Individual milk yields were recorded daily, and 2 a.m.-p.m. milk samples were taken for composition analyses per period. Thirty-two cows went through the trial.

${ }^{2}$ Fan+SP barn $=$ freestall barn with fans and sprinklers (control); TP barn = tunnel-ventilated, water-padded barn; $\mathrm{TP}+\mathrm{SP}$ barn $=\mathrm{TP}$ barn with sprinklers.

$\mathrm{NS}=P>0.05 ;{ }^{*} P<0.05$

less time lying down in the hot and humid conditions of this trial. This observation is consistent with cow behavior studies that demonstrate that cows suffering heat stress eat more frequent, smaller meals and, to increase the surface area available for dissipating body heat, stand for a longer periods.

After 2 offerings of fresh TMR, cow intake increased significantly (Figure 4). Forty-three to $54 \%$ of cows ate up to $2 \mathrm{~h}$ after the a.m. feeding. During an extended period after the p.m. feeding, 51 to $68 \%$ of cows were eating $2.5 \mathrm{~h}$ after feed offering, and cows in the Fan+SP barn were more willing to eat than cows in the TP barn $(P=0.11$, Table 5$)$. Intake activity in other periods was generally lower than $25 \%$. The lowest intake activity (only 6.3 to $12.6 \%$ eating) occurred near noon and from midnight to dawn. The intensity of daytime intake activity was greatest in the Fan+SP barn, intermediate in the TP+SP barn, and lowest in the TP barn. In our previous study, the intake activity in the TP environment was $43 \%$ less after the p.m. feeding than that seen in the Fan+SP group (35.7 vs. $62.1 \% ; P<0.05$; Shiao et al., 2009b). By increasing air speed and sprinkler cooling, the TP and TP+SP barns offered cows a more comfortable environment, increasing the intake activity of the p.m. main meal to 75 and $91 \%$ of that of the control group.

Rumen Digestion. The diet offered to all cows in this study consisted of $50 \%$ forage, $24 \%$ by-products, and $26 \%$ corn-soybean meal concentrate and contained $39 \%$ DM, $16.5 \%$ CP, 32.1\% ADF, and $50.0 \%$ NDF (DM basis). Cows had similar intake activity and a similar rumen digestion pattern in this trial (Figure 5). The weighted averages of diurnal rumen $\mathrm{pH}$ were similar: $6.24,6.12$, and 6.20 for cows in the Fan+SP, TP, and $\mathrm{TP}+\mathrm{SP}$ barns, respectively (Figure $5 \mathrm{~A}$ ). The highest rumen $\mathrm{pH}$ value of 6.47 was seen around $0700 \mathrm{~h}$, just before the a.m. feeding. The lowest $\mathrm{pH}$ value $(5.90)$ occurred approximately $5 \mathrm{~h}$ after the p.m. feeding, around $2000 \mathrm{~h}$. The lowest $\mathrm{NH}_{3}-\mathrm{N}$ level was higher in cows in the TP barn than in those in the Fan+SP barn (11.7 vs. $8.0 \mathrm{mg} \%$; $P<0.05)$. The weighted diurnal average $\mathrm{NH}_{3}-\mathrm{N}$ level of cows in the TP barn tended to be higher than that of cows in the other 2 barns ( 15.0 vs. 13.1 $\mathrm{mg} \% ; P=0.06)$. The rumen $\mathrm{NH}_{3}-\mathrm{N}$ level in this trial was relatively stable between 10 and $20 \mathrm{mg} \%$ (Figure $5 B)$. Rumen total VFA production and individual VFA molar percentages were similar across the 3 barn treatments. The weighed rumen total VFA concentrations of cows in the Fan $+\mathrm{SP}, \mathrm{TP}$, and $\mathrm{TP}+\mathrm{SP}$ barns were 110 , 112, and $104 \mathrm{~m} M$, respectively (Figure 5C).

Lactation Performance. Cow BW was not affected by barn cooling treatments (Table 6 ). In 2005, the adverse environment in the TP barn decreased cow DMI by $7.6 \%(17.0$ vs. $18.4 \mathrm{~kg})$ and milk yield by $10.1 \%(4 \%$ FCM, 23.1 vs. $25.7 \mathrm{~kg} ; P<0.001$; Shiao et al., 2009b). In the 2006 trial, the decremented DMI and milk yield problems had been resolved and even improved. The improved TP and TP+SP barns were associated with a small but significant increase in DMI relative to the Fan+SP barn (18.8 vs. $18.5 \mathrm{~kg} ; P<0.05)$. The improved environment of both water-padded barns stimulated cow intake and resulted in higher milk yields. The milk yield of cows in the TP barn matched that of cows in the Fan+SP barn, and cows in the $\mathrm{TP}+\mathrm{SP}$ barn 
produced $3 \%$ more milk than cows in the control barn ( 25.4 vs. $24.7 \mathrm{~kg} ; P=0.10$ ). In this study, the low air speed at night in the water-padded barn contributed to cow heat stress. Although milk production was greatly improved in 2006 compared with 2005, we believe that further improvement is possible. Smith et al. (2006b) reported an $11 \%$ increase in DMI and an increase of 2 $\mathrm{kg}$ of milk/cow per day. The milk protein concentration of cows in the TP+SP barn was lower than that of the other 2 groups, and the cause of this finding is not clear. The concentrations of milk fat, lactose, and total solids were not affected by barn cooling treatments. Smith et al. (2006b) reported that reducing heat stress would decrease SCC in raw milk. Their tunnel ventilation evaporative cooling decreased SCC by $27 \%$ compared with the Fan+SP barn. In the present study, the TP and $\mathrm{TP}+\mathrm{SP}$ barns both improved cow udder health, indicating that the SCC in milk decreased substantially (43 and 54\%, respectively; $P=0.13$ ).

\section{CONCLUSIONS}

Increasing air speed and using sprinkler cooling significantly increased the potential efficacy and feasibility of the use of a TP+SP barn to alleviate cow heat stress in our hot and humid environment. Tunnel-ventilated, water-padded barns reduced daytime $\mathrm{T}$ more efficiently than did the Fan+SP barn. The high humidity found in a water-padded barn could be partially mitigated by increasing air speed. When daytime air speed increased from 1.66 to $2.38 \mathrm{~m} / \mathrm{s}$, cows in the TP and Fan+SP barns produced similar quantities of milk. When daytime air speed increased from 1.66 to 2.06 $\mathrm{m} / \mathrm{s}$ in conjunction with sprinkling, cows in the $\mathrm{TP}+\mathrm{SP}$ barn produced $3 \%$ more milk than cows in the Fan+SP barn. Research regarding further modification and evaluation of water-padded barns is continuing at LRI. The key contributors to improvement include sufficient air speed and sprinkler cooling.

\section{ACKNOWLEDGMENTS}

We particularly thank the staff of the Livestock Research Institute (LRI) dairy farm (Taiwan, Republic of China) for cow husbandry and sample procurement. We thank the staff in the nutrition laboratory at LRI for sample analysis.

\section{REFERENCES}

Abeni, F., L. Calamari, and L. Stefanini. 2007. Metabolic conditions of lactating Friesian cows during the hot season in the Po valley. 1. Blood indicators of heat stress. Int. J. Biometeorol. 52:87-96. Armstrong, D. V. 1994. Heat stress interaction with shade and cooling. J. Dairy Sci. 77:2044-2050.
Beede, D. K., and R. J. Collier. 1986. Potential nutritional strategies for intensively managed cattle during thermal stress. J. Anim. Sci. $62: 543-554$.

Bengtsson, L. P., and J. H. Whitaker. 1988. Farm Structures in Tropical Climates. Food and Agriculture Organization of the United Nations, Rome, Italy.

Berman, A. 2010. Forced heat loss from body surface reduces heat flow to body surface. J. Dairy Sci. 93:242-248.

Berman, A., Y. Folman, M. Kaim, M. Mamen, Z. Herz, D. Wolfenson, A. Arieli, and Y. Graber. 1985. Upper critical temperature and forced ventilation effects for high-yielding dairy cattle in a subtropical climate. J. Dairy Sci. 68:1488-1495.

Bianca, W. 1962. Relative importance of dry- and wet-bulb temperatures in causing heat stress in cattle. Nature 195:251-252.

Bray, D. R., D. K. Beede, R. A. Bucklin, and G. L. Hahn. 1992. Cooling, shade, and sprinkling. Page 655-663 in Large Dairy Herd Management. H. H. Van Horn and C. J. Wilcox, ed. Am. Dairy Sci. Assoc., Champaign, IL.

Brouk, M. J., D. V. Armstrong, J. F. Smith, M. J. VanBaale, D. B. Bray, and J. P. Harner III. 2010. Evaluating and selecting cooling systems for different climates. Accessed Apr. 27, 2010. http:// www.extension.org/pages/Evaluating_and_Selecting_Cooling_ Systems_for_Differnet_Climates.

Bucklin, R. A., L. W. Turner, D. K. Beede, D. R. Bray, and R. W. Hemken. 1991. Methods to relieve heat stress for dairy cows in hot, humid climates. Appl. Eng. Agric. 7:241-247.

Calamari, L., F. Abeni, F. Calegari, and L. Stefanini. 2007. Metabolic conditions of lactating Friesian cows during the hot season in the Po valley. 2. Blood minerals and acid-base chemistry. Int. J. Biometeorol. 52:97-107.

Chastain, J. P., and L. W. Turner. 1994. Practical results of a model of direct evaporative cooling of dairy cows. Pages 337-352 in Proc. 3rd Int. Dairy Housing Conf. Am. Soc. Agric. Eng., St. Joseph, MI.

Chen, J. Y., C. C. Yeh, K. H. Lee, C. L. Chang, T. F. Shiao, C. H. Hsieh, C. H. Jung, and Y. N. Jiang. 2009. The relationship between temperature-humidity index in barn and the performances of dairy cows in different seasons. Taiwan Livest. Res. 42:1-12.

Collier, R. J., G. E. Dahl, and M. J. VanBaale. 2006. Major advances associated with environmental effects on dairy cattle. J. Dairy Sci. 89:1244-1253.

Dikmen, S., and P. J. Hansen. 2009. Is the temperature-humidity index the best indicator of heat stress in lactating dairy cows in a subtropical environment? J. Dairy Sci. 92:109-116.

Flamenbaum, I., and E. Ezra. 2007. Effect of level of production and intensive cooling in summer on productive and reproductive performance of high yielding dairy cows. J. Dairy Sci. 90(Suppl. 1):345. (Abstr.)

Gooch, C. A., and M. B. Timmons. 2000. Tunnel ventilation for freestall barns. Pages 186-201. in Proc. Dairy Housing and Equipment Systems: Managing and Planning for Profitability. NRAES-129, Natural Resource, Agric., Engineering Service, Ithaca, NY.

Grant, R. 2007. Taking advantage of natural behavior improves dairy cow performance. Pages 225-236 in Proc. Western Dairy Manage. Conf., Reno, NV.

Hahn, G. L. 1985. Management and housing of farm animals in hot environments. Page 151 in Stress Physiology in Livestock. M. K. Yousef, ed. CRC Press, Boca Raton, FL.

Hahn, G. L. 1994. Environmental requirements of farm animals. Pages 220-235 in Handbook of Agricultural Meteorology. J. F. Griffith, ed. Oxford Univ. Press, New York, NY.

Hahn, G. L., J. B. Gaughan, T. L. Mader, and R. A. Eigenberg. 2009. Thermal indices and their application for livestock environments. Pages 113-130 in Livestock Energetics and Thermal Environmental Management. J. A. DeShazer, ed. Am. Soc. Agric. Biol. Eng., St. Joseph, MI.

Hahn, G. L., A. M. Parkhurst, and J. B. Gaughan. 1997. Cattle respiration rate as a function of ambient temperature. Paper \# MC97121. Am. Soc. Agric. Eng. Midwest Mtg. Am. Soc. Agric. Eng., St. Joseph, MI. 
Hillman, P. E., K. G. Gebremedhin, A. Parkhurst, J. Fuquay, and S. Willard. 2001. Evaporative and convective cooling of cows in a hot and humid environment. Pages 343-350 in Livestock Environment VI, Proc. 6th Int. Livest. Environ. Symp. Am. Soc. Agric. Eng., St. Joseph, MI.

Hillman, P. E., C. N. Lee, and S. T. Willard. 2005. Thermoregulatory responses associated with lying and standing in heat-stressed dairy cows. Trans. ASAE 48:795-801.

Koubková, M., I. Knížková, P. Kunc, H. Härtlová, J. Flusser, and O. Doležal. 2002. Influence of high environmental temperatures and evaporative cooling on some physiological, hematological and biochemical parameters in high-yielding dairy cows. Czech J. Anim. Sci. 47:309-318.

Lee, C. F., C. P. Chen, C. R. Wu, and T. F. Shiao. 2003. Effects of one additional night feeding on milking performance and ruminal digestion of Holstein lactating cows in hot summer. J. Chin. Soc. Anim. Sci. 32:99-110.

Lee, S. N., C. F. Lieu, Y. M. Hsu, T. W. Yang, T. T. Chen, T. H. Ku, and T. S. Liang. 1999. Sprinkling and forced ventilation effects on physiological and reproductive responses of dairy cows during hot season. Taiwan Livest. Res. 32:117-128.

Maia, A. S. C., R. G. daSilva, and C. M. B. Loureiro. 2005a. Respiratory heat loss of Holstein cows in a tropical environment. Int. J. Biometeorol. 49:332-336.

Maia, A. S. C., R. G. daSilva, and C. M. B. Loureiro. 2005b. Sensible and latent heat loss from the body surface of Holstein cows in a tropical environment. Int. J. Biometeorol. 50:17-22.

NOAA. 1976. Livestock hot weather stress. Operations Manual Letter C-31-76. NOAA, Kansas, MO.

NRC. 2001. Nutrient Requirements of Dairy Cattle. 7th rev. ed. Natl. Acad. Sci., Washington, DC.

Reece, W. O. 1993. Respiration in mammals. Pages 263-293 in Ducks' Physiology of Domestic Animal. 11th ed. M. J. Swenson and W. O. Reece, ed. Cornell Univ. Press, Ithaca, NY.

Ryan, D. P., M. P. Boland, E. Kopel, D. Armstrong, L. Munyakazi, R. A. Godje, and R. H. Ingraham. 1992. Evaluating two different evaporative cooling management systems for dairy cows in a hot, dry climate. J. Dairy Sci. 75:1052-1059.

Sabuncuoglu, N., O. Coban, E. Lacin, A. Yildiz, O. Akbulut, A. V. Yaganoglu, and Y. Sagsoz. 2008. Effect of barn ventilation on blood gas status and some physiological traits of dairy cows. J. Environ. Biol. 29:107-110.

Sanchez, W. K., M. A. McGuire, and D. K. Beede. 1994. Macromineral nutrition by heat stress interactions in dairy cattle: Review and original research. J. Dairy Sci. 77:2051-2079.

SAS Institute. 2003. Statistics User Guide. Version 9.1. SAS Inst. Inc., Cary, NC.

Shiao, T. F., D. W. Yang, H. F. Lee, C. H. Hsieh, S. N. Lee, and C. F. Lee. 2009a. Feasibility assessment of heat stress alleviation for Holstein lactating cows by water-padding barn in Taiwan. I: Barn environment and cows' physiological responses. J. Chin. Soc. Anim. Sci. 38:183-198.

Shiao, T. F., D. W. Yang, H. F. Lee, C. H. Hsieh, S. N. Lee, and C. F. Lee. 2009b. Feasibility assessment of heat stress alleviation for Holstein lactating cows by water-padding barn in Taiwan. II: Intake activity, rumen digestion and lactation performance. J. Chin. Soc. Anim. Sci. 38:199-215.

Smith, T. R., A. Chapa, S. Willard, C. Herndon Jr., R. J. Williams, J. Crouch, T. Riley, and D. Pogue. 2006a. Evaporative tunnel cooling of dairy cows in the southeast. I: Effect on body temperatures and respiration rates. J. Dairy Sci. 89:3904-3914.

Smith, T. R., A. Chapa, S. Willard, C. Herndon Jr., R. J. Williams, J. Crouch, T. Riley, and D. Pogue. 2006b. Evaporative tunnel cooling of dairy cows in the southeast. II: Impact on lactation performance. J. Dairy Sci. 89:3915-3923.

West, J. W. 2003. Effects of heat-stress on production in dairy cattle. J. Dairy Sci. 86:2131-2144.

West, J. W., K. D. Haydon, B. G. Mullinix, and T. G. Sandifer. 1992. Dietary cation-anion balance and cation source effects on production and acid-base status of heat-stressed cows. J. Dairy Sci. $75: 2776-2786$. 